\title{
Материалы Тувинского отряда Саяно-Алтайской экспедиции 1952 и 1953 гг. на негативах из собрания Кунсткамеры
}

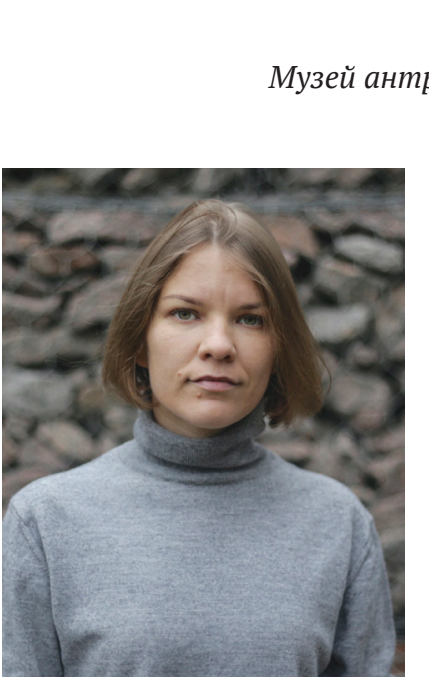

Надежда А. Станулевич

Музей антропологии и этнографии имени Петра Великого (Кунсткамера) РАН, Российская Федерация позиция Тувинского областного краеведческого музея.

Основной проблемой в научном изучении коллекций стала краткость описаний, которые составляли собиратели при регистрации своих материалов, отсутствие информации о фотографах, редкость перечисления лиц на групповых снимках.

Ключевые слова: Тува; Кунсткамера; тувинцы; Екатерина Дмитриевна Прокофьева; Александр Данилович Грач; история тувиноведения; фотография; фотографическая коллекция; негатив; музейная коллекция; культурное наследue

\section{Для циитирования:}

Станулевич Н.А. Материалы Тувинского отряда Саяно-Алтайской экспедиции 1952 и 1953 гг. на негативах из собрания Кунсткамеры // Новые исследования Тувы. 2020, № 3. C. 240-252. DOI: www.doi.org/10.25178/nit.2020.3.17

Станулевич Надежда Алексеевна - кандидат исторических наук, младший научный сотрудник Лаборатории музейных технологий Музея антропологии и этнографии имени Петра Великого (Кунсткамера) РАН. Адрес: 199034, Россия, г. Санкт-Петербург, Университетская наб., д. 3. Тел.: +7 (904) 556-16-68. Эл. адрес: nadstanul@kunstkamera.ru

STANULEVICH, Nadezhda Alexeevna, Candidate of History, Junior Research Fellow, Laboratory of Museum Technologies, Peter the Great Museum of Anthropology and Ethnography (Kunstkamera) Russian Academy of Sciences. Postal address: 3 Universitetskaya Emb., 199034 Saint-Petersburg, Russian Federation. Tel.: +7 (904) 556-16-68. E-mail: nadstanul@kunstkamera.ru 


\title{
Expeditionary negatives of Tuva in the Kunstkamera collection, 1952 and 1953
}

\author{
Nadezhda A. Stanulevich \\ Peter the Great Museum of Anthropology and Ethnography, RAS, Russian Federation
}

\begin{abstract}
The article presents an overview of the collection of photographic negatives (the number of frames, the type of film used, and the completeness of the scientific description of objects) taken by E. D. Prokofieva and A. D. Grach in 1952 and 1953 as part of the Tuvan team of the Sayan-Altay expedition of the Academy of Sciences of the Soviet Union. Our study relies on the information from the record of entry at the Peter the Great Museum of Anthropology and Ethnography, its inventories and the collectors' publications. The article introduces the collection of negatives, focusing specifically on some images characteristic of the main shooting scenes.

We also examine some issues of probable tampering with the original images, such as cropping or changing contrast, when field materials were being prepared for publication. Also identified and classified are both the materials which have been published and those negatives that were not included in any publications.

The article marks thematic clusters in E. D. Prokofieva's and A. D. Grach's negatives collections, such as archaeological, ethnographic and anthropological surveying; everyday work of the expedition; individual and group portraits; landscapes; and collections of the Tuvan regional museum.

The main challenges for our study were the brevity of the labelling and description of the materials as they were registered by the collectors, the lack of information about photographers, and the group shots which rarely listed those in the photo.
\end{abstract}

Keywords: Tuva; Kunstkamera; Tuvans; Ekaterina Dmitrievna Prokofieva; Alexandr Danilovich Grach; history of Tuvan studies; photography; photography collection; negative; museum collection; cultural heritage

\section{For citation:}

Stanulevich N. A. Materialy Tuvinskogo otriada Saiano-Altaiskoi ekspeditsii 1952 i 1953 gg. na negativakh iz sobraniia Kunstkamery [Expeditionary negatives of Tuva in the Kunstkamera collection, 1952 and 1953]. New Research of Tuva, 2020, no. 3, pp. 240-252. (In Russ.). DOI: www.doi.org/10.25178/nit.2020.3.17

\section{Введение}

В первой половине 1950-х гг. отряды Саяно-Алтайской экспедиции Академии наук СССР проводили активные археологические, этнографические и антропологические исследования на территории Тувы. Полученные ими материалы о быте и культуре тувинцев стали источниковедческой основой для дальнейших исследований, толчком для развития тувиноведения, связанного с именами таких ученых, как С. И. Вайнштейн, Л. П. Потапов, В. П. Дьяконова, Е. Д. Прокофьева, П. И. Каралькин и др. (Вайнштейн, 1961, 1972, 2009; Дьяконова, 1975; Каралькин, 1960; Потапов, 1969; Прокофьева, 2011, см.: Иргит, 2013).

В документации Музея антропологии и этнографии им. Петра Великого (Кунсткамера) РАН (далее МАЭ) эта группа исследователей получила название «Тувинских отрядов» с уточнением по сезонам, проведенным в поле. Дневники полевых исследований, описи материалов и негативы со съемок во время экспедиции хранятся в Научном архиве, Отделе учета и Негатеке МАЭ. В данной публикация будут рассмотрены коллекции негативов общим числом в 2103 кадра, привезенных Е. Д. Прокофьевой и А. Д. Грачом в 1952 и 1953 гг., как наиболее яркие иллюстративные материалы, полученные Тувинским отрядом. Интересующие нас экспедиции смогли собрать удивительно много информации о традиционной жизни тувинцев, коллективизации, экономических и социальных преобразованиях в Туве (Кисель, 2012) во второй половине XX в.

Этнограф Екатерина Дмитриевна Прокофьева (1902-1978) возглавляла в 1952, 1953 и 1955 гг. так называемый Тувинский отряд под начальством Леонида Павловича Потапова (1905-2000), руководителя Ленинградской части Института Этнографии АН СССР (Кисель, 2011b: 20). В этот период были совершены первые разведывательные маршруты по труднодоступным районам Западной Тувы, сос- 
тавлены археологические карты, впервые открыты многочисленные скопления петроглифов и большая серия древнетюркских каменных изваяний (Савинов, Длужевская, 1998: 8). Для археолога Александра Даниловича Грача (1928-1981) сезон 1953 г. определил его дальнейший научный интерес - изучение древностей Тувы (Грач, 1961a, 1980).

Целью данной статьи является введение в научный оборот информации о коллекциях негативов Тувинского отряда за 1952 и 1953 гг., выявление особенностей использования изображений в качестве иллюстраций к научным трудам членов экспедиций.

В представленной публикации впервые приводится систематизация фотографических материалов по тематическому признаку, благодаря которой проведена переатрибуция изображений, относящихся к индивидуальным и групповым портретам, в том числе и участников экспедиций.

Источниковой базой исследования является коллекции негативов и учетная документация МАЭ (Книги поступления, коллекционные описи), иллюстрации из рукописей и опубликованных работ А. Д. Грача и Е. Д. Прокофьевой.

\section{Общие характеристики коллекций негативов}

Е. Д. Прокофьева осуществила работу по регистрации негативов из экспедиции сезона 1952 г. спустя три года - в январе 1955 г., сформировав коллекцию с учетным обозначением МАЭ И 1612. Негативы из экспедиции 1953 г. были зарегистрированы ею в два этапа - в декабре 1954 г. и декабре 1955 г.: коллекции МАЭ И 1600 и МАЭ И 1611 - соответственно.

А. Д. Грач провел регистрацию негативов в коллекцию МАЭ И 1595 в октябре 1954 г., а также в феврале 1955 г. - МАЭ И 1617.

В сезоне 1952 г. Е. Д. Прокофьева использовала для фотосъемки пленку ФЭД формата 35 мм (2,4×3,6 cм), отсняв 447 кадров. В следующем экспедиционном сезоне на пленку того же типа было отснято 299 и 591 кадр в коллекциях МАЭ И 1600 и МАЭ И 1611 - соответственно.

Коллекции МАЭ И 1595, МАЭ И 1617 состоят из 510 и 256 черно-белых негативов на пленке, с которой работал А. Д. Грач. В первом случае для съемки была использована фотопленка формата $6 \times 9$ см, а во втором - разных форматов: 9×12 см, 13×18 см и пленка ФЭД 35 мм (2,4×3,6 см).

Каждому снимку А. Д. Грач дал краткое описание. Тексты к негативам, сохранившиеся в описях собирателя, формальны и не являются развернутыми; они не передают полное содержание изображенного сюжета. Тем не менее, за годы научной работы исследователь ввел в научный оборот наибольшее число материалов, отснятых в своей первой экспедиции.

Подписи, сделанные Е. Д. Прокофьевой, отличаются от подписей ее младшего коллеги полнотой описания и наличием дополнительной информации, позволяющей не только точно атрибутировать предметы, но и составить представление о собранном материале.

В коллекционных описях А. Д. Грач и Е. Д. Прокофьева числятся собирателями материалов. Указание обоих исследователей в качестве фотографов для соответствующих коллекций не представляется на данный момент возможным, так как требует внимательного изучения каждого кадра с учетом присутствующих на фотографиях лиц, а также той информации, что в ряде археологических маршрутов в качестве фотографа в 1953 г. выступал сотрудник Института этнографии АН СССР Алексей Васильевич Маторин (Грач, 1955: 402).

\section{Основные сюжеты в коллекциия А. Д. Грача и их использование в публикациях собирателя}

Значительная часть негативов, зарегистрированных А. Д. Грачом, отображает археологическую работу на территории Западной Тувы. В 1953 г. отрядом было открыто два новых каменных изваяния на территории Монгун-Тайгинского кожууна. Изображения фигур ${ }^{1}$ с оградками было представлено в соответствующей публикации исследователя (Грач, 1955). Также было дообследовано ранее неопубликованное изваяние на территории сумона Бай-Тал, открытое Л. П. Поповым в 1949 г. (там же: 402 ). Последний памятник на момент работы отряда состоял уже из нескольких частей. Голова изваяния

${ }^{1}$ Изваяния № 1: рис. 1 - МАЭ И 1595-56, рис. 2 - МАЭ И 1617-52, рис. 3 - МАЭ И 1595-54; изваяние № 2: рис. 8 МАЭ И 1595-161, рис. 9 - МАЭ И 1595-133, рис. 10 - МАЭ И 1595-160, согласно нумерации иллюстраций в статье (Грач, 1955). 
была позднее доставлена в Ленинград, стала частью коллекции Кунсткамеры и была зарегистрирована под номером МАЭ № 6119. А. Д. Грач сделал снимки этой части памятника уже в 1954 г. по прибытии в музей ${ }^{1}$.

Помимо реконструкции облика в случае разрушения изваяния, отряд устанавливал его первоначальное местоположение, в ситуации, когда на месте было ясно, что объект был перемещен ранее. Так, каменное изваяние, по описаниям А. Д. Грача находившееся «в степи Манайлыг-Хову (приблизительно на полпути между Шеми-Аксы и Чыргакы-Аксы)» (там же: 420), было перемещено. Находка места предыдущей установки изваяния происходила следующим образом, описанным в публикации исследователя. «Идя по глубокому следу, мы обнаружили яму, в которой некогда было вкопано изваяние (расстояние - около 100 м от тракта). Надо думать, что изваяние подобно подавляющему большинству памятников этого рода в момент первоначальной своей установки было обращено лицом на восток» (там же). Лежащая на земле каменная фигура была заснята с разных ракурсов ${ }^{2}$, яма со следом от основания изваяния запечатлена на негативе МАЭ И 1595-238 (фото 1). Помимо описанных выше каменных статуй, А. Д. Грач в публикации 1955 г. привел изображения фигур, которые были открыты другими экспедициями ранее, а Тувинским отрядом обследовались повторно.

Разведывательные работы 1953 г. позволили А. Д. Грачу и его коллегам зафиксировать местоположение могильников, наскальных изображений разных исторических эпох и создать должную базу для планирования работ комплексной стационарной экспедиции (Грач, 1980: 13). Негативы из коллекций МАЭ И 1595, МАЭ И 1617 были использованы их собирателем как богатый иллюстративный материал для публикации о петроглифах Тувы (Грач, 1957). При анализе подписей к изображениям к данной статье нами было выявлено, что часть из них ${ }^{3}$ не имеет номеров коллекций МАЭ. В типографских подписях имеется лишь указание на принадлежности к музейному собранию МАЭ. На данном этапе исследования можно предположить, что негативы или отпечатки, с которых были сделаны эти иллюстрации, являются частью либо других коллекций, в том числе МАЭ, либо находятся среди полевых материалов А. Д. Грача в Рукописном отделе Научного архива Института истории материальной культуры РАН (НА ИИМК РАН, РО, ф. 66) 4 .

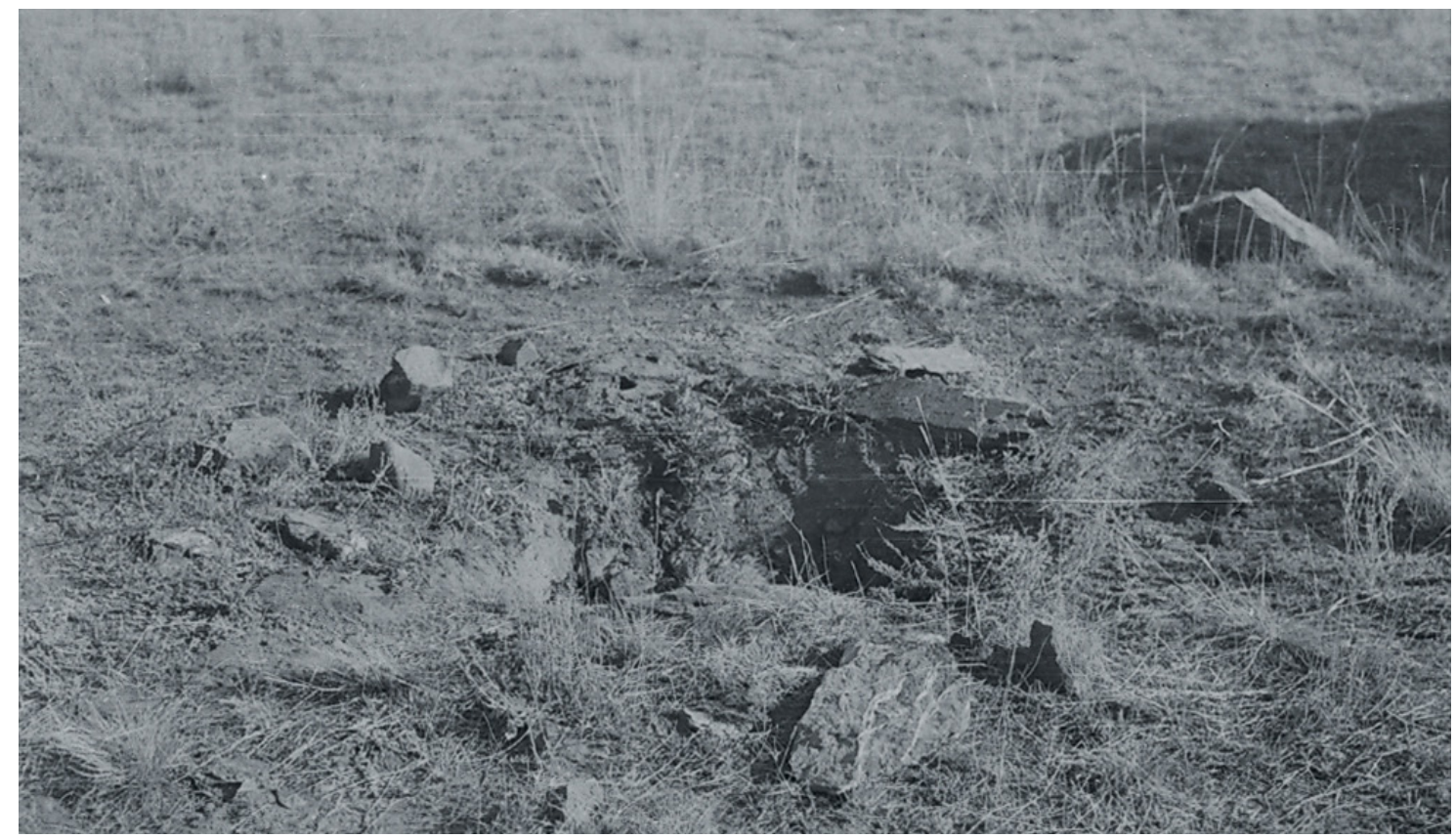

Фото 1. Место, где было установлено каменное изваяние в степи Манайлыг-Хову, на полпути между Шеми-Аксы и Чыргакы-Аксы. Фото А. Д. Грача (?), 1953 г. МАЭ И 1595-238. Photo 1. The location where a stone statue was placed in the Manaylyg-Khovu steppe,

midway between Shemi-Aksy and Chyrgaky-Aksy. Photo by A. D. Grach (?). 1953. MAE I 1595-238.

\footnotetext{
${ }^{1}$ МАЭ И 1617-254, МАЭ И 1617-255.

${ }^{2}$ МАЭ И $1595-233 \div 236$, МАЭ И $1617-60 \div 64$.

${ }^{3}$ Таблицы XXVIII-XXXII, согласно нумерации в статье (Грач, 1957).

${ }^{4}$ На момент публикации фонд находится в процессе научно-технической обработки сотрудниками архива.
} 


\section{НОВЫЕ ИССЛЕДОВАНИЯ ТУВЫ}

www.nit.tuva.asia
No3

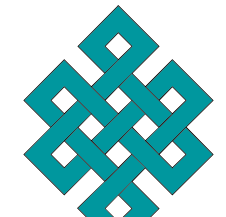

2020
THE NEW RESEARCH OF TUVA

Novye issledovaniia Tuvy

А.Д.Грач активно публиковал материалы экспедиции 1953 г. в своих научных статьях и монографиях (Грач, 1955, 1957, 1961a, 1980). Подписи под опубликованными фотографиями служат источником информации для атрибуции негативов, опись к которым была составлена весьма кратко (МАЭ РАН, опись коллекции МАЭ И 1595, опись коллекции МАЭ И 1617). Так становится известно, об авторстве некоторых кадров, включенных в качестве иллюстраций для издания о каменных изваяниях Тувы (Грач, 1955). При этом А. Д. Грач использует формулировку «фото автора» ${ }^{1}$, либо указывает, что снимок был сделан его коллегой А. Д. Маториным. В ходе работы с музейными коллекциями были выявлена техническая ошибка при указании в публикации 1955 г. двух изображений из коллекции МАЭ И 1617-51 и МАЭ И 1617-53, которые получили неверную индексацию. А именно, рис. 4а ошибочно подписан как МАЭ №И-1617-51, а рис. 46 - МАЭ №И-1617-53 (там же: 405). Сличение изображений из публикации и отсканированных негативов показало, что рис. 4а соответствует негатив МАЭ И 1617-53, рис. 46 - МАЭ И 1617-51.

Результаты этой экспедиции в дальнейшем были использованы А.Д. Грачом для проведения комплексного археологического исследования памятников различного времени на территории Тувы, по результатам которого им была написана монография (Грач, 1961a), защищенная в качестве кандидатской диссертации (Грач, 1961b; см. также: Савинов, Длужевская, 1998: 8).

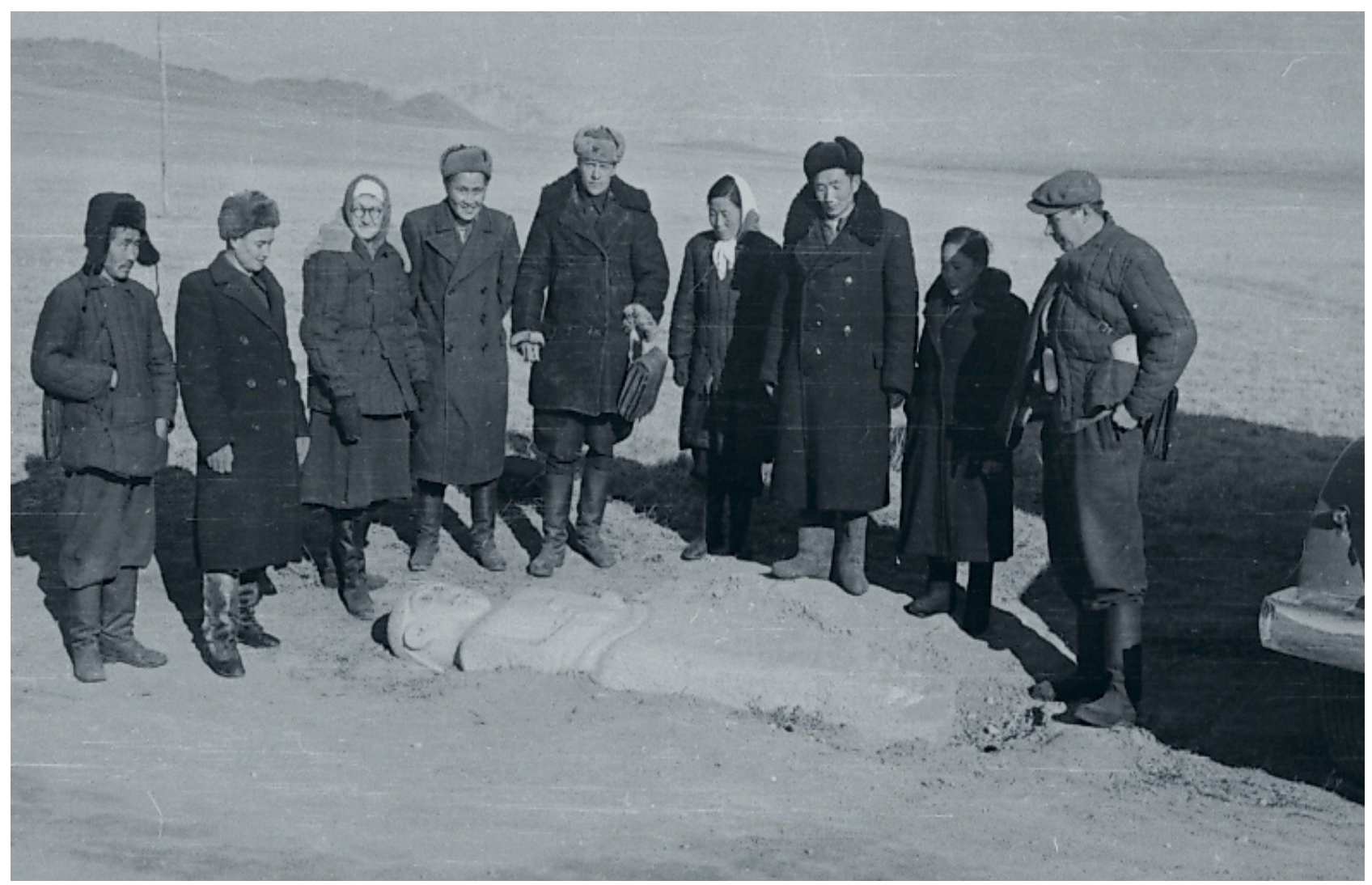

Фото 2. Участники Саяно-Алтайской экспедиции рядом с каменным изваянием в степи Манайлыг-Хову, на полпути между Шеми-Аксы и Чыргакы-Аксы. Фото А. Д. Грача (?), 1953 г. МАЭ И 1595-237. Photo 2. Members of the Sayan-Altai expedition near the stone statue in the Manaylyg-Khovu steppe, midway between Shemi-Aksy and Chyrgaky-Aksy. Photo by A. D. Grach (?), 1953. MAE I 1595-237.

${ }^{1}$ Фотографии, подписанные как работы А. Д. Грача: рис. 1 - МАЭ И 1595-56, рис. 3 - МАЭ И 1595-54, рис. 6 МАЭ И 1595-59, рис. 7 - МАЭ И 1595-153, рис. 8 - МАЭ И 1595-161, рис. 9 - МАЭ И 1595-133, рис. 10 - МАЭ И 1595-160, рис. 11 - МАЭ И 1595-142, рис. 12 - МАЭ И 1595-144, рис. 14 - МАЭ И 1595-478, рис. 18 - МАЭ И 1595-234, согласно нумерации иллюстраций в статье (Грач, 1955: 403, вклейка 404-405, 408, 410, 412, 412, 413, $414,415,417,421)$.

Фотографии, подписанные как работы А. В. Маторина: рис. 2 - МАЭ И 1617-52, рис. 4а - МАЭ 1617-53, рис. 46 МАЭ И 1617-51, рис. 15 - МАЭ И 1617-199, рис. 16а - МАЭ И 1617-196, рис. 16 - МАЭ И 1617-197, рис. 17 - МАЭ И 1617-194, согласно нумерации иллюстраций в статье (Грач, 1955: 404, 405, 405, 418, 419, 419, 420). 


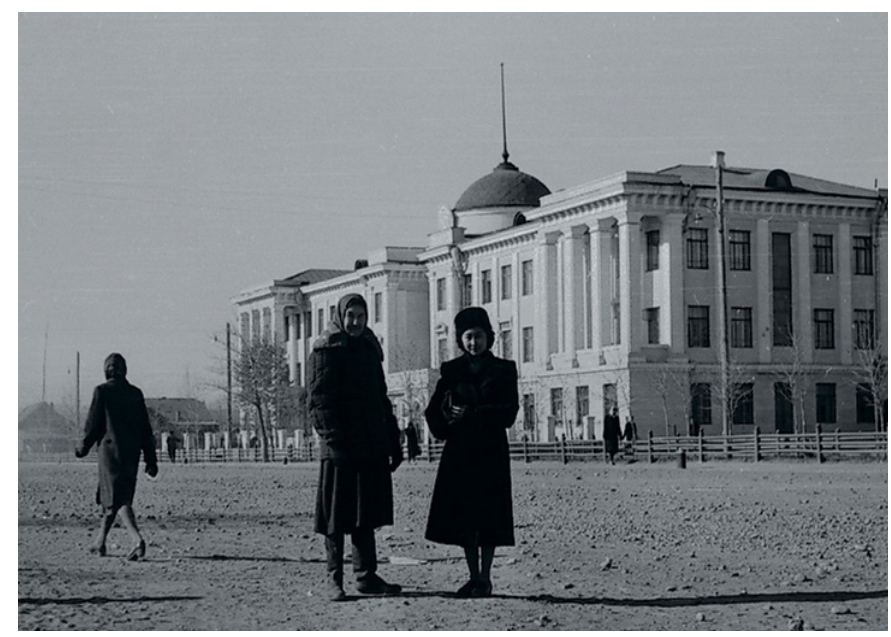

Фото 3. Женщины (слева Е. Д. Прокофьева) на фоне Облисполкома в городе Кызыл. Фото А. Д. Грача (?), 1953 г. МАЭ И 1595-222. Photo 3. Women (E. D. Prokofieva on the left) in front of the building of the regional Executive committee, Kyzyl.

Photo by A. D. Grach (?), 1953. MAE I 1595-222.

Фото 4. Каменная стела на археологической экспозиции Тувинского областного краеведческого музея. Фото А. Д. Грача (?), 1953 г. МАЭ И 1617-241.

Photo 4. A stone stele on display at the archaeological exposition of Tuvan Oblast' Regional Museum.

Photo by A. D. Grach (?), 1953. MAE I 1617-241.

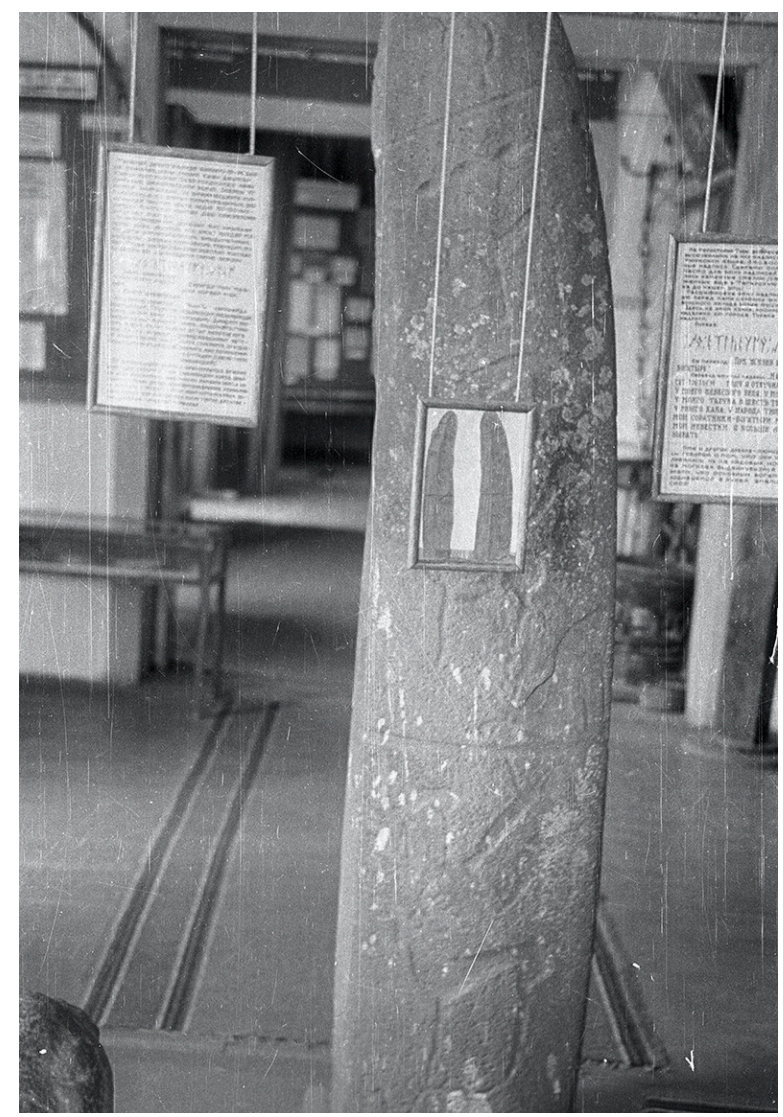

Тем не менее, неопубликованными остаются те кадры, на которых запечатлены сюжеты отличные от археологических работ, обследований территорий и видов местностей, курганов и т. п. Нам хотелось бы упомянуть тематические блоки в коллекциях, не относящиеся к основному роду деятельности экспедиций. В коллекции МАЭ И 1595 - это рабочие моменты в деятельности Тувинского отряда экспедиции (фото 2), индивидуальные и групповые портреты (фото 3), снимки этнографического характера, пейзажная съемка. Исследователям различного профиля могут быть интересны фотографии, на которых запечатлены члены экспедиционного отряда, в том числе А. Д. Грач ${ }^{1}$ и Е. Д. Прокофьева ${ }^{2}$. Такие портреты были определены после сканирования материалов и визуального осмотра каждого кадра, в связи с отсутствием упоминания о фотографируемых лицах в описях коллекций МАЭ И 1595 и МАЭ И 1617, оформленных А. Д. Грачом. В коллекции МАЭ И 1617, помимо перечисленных выше тематических блоков, присутствуют снимки музейных предметов в экспозиции Тувинского областного краеведческого музея ${ }^{3}$ (фото 4).

\section{Предпечатная обработка иллюстративных материалов, на примере исполь- зования негативов А. Д. Грача в его публикациях}

Необходимо отметить особенности работы с исходными негативами или фотографическими отпечатками для публикации их в изданиях второй половины XX в.

Для научных статей было возможным значительное кадрирование части изображения с целью уменьшения количества лишних деталей и фокусировки внимания читателя на объекте исследования. Имело место и работа с контрастностью всего изображения или его частей. На итоговой

\footnotetext{
${ }^{1}$ А. Д. Грач на групповых портретах: МАЭ И 1595-11, МАЭ И 1595-12, МАЭ И 1595-47, МАЭ И $1617-93$. Индивидуальные портреты А. Д. Грача: МАЭ И 1595-13, МАЭ И 1595-165, МАЭ И 1595-218.

${ }^{2}$ Е. Д. Прокофьева на групповых портретах: МАЭ И 1595-11, МАЭ И 1595-12, МАЭ И 1595-40, МАЭ И 1595-41, МАЭ И 1595-42, МАЭ И 1595-43, МАЭ И 1595-222, МАЭ И 1595-226, МАЭ И 1595-232, МАЭ И 1595-237, МАЭ И 1595-508, МАЭ И 1617-94, МАЭ И 1617-95.

${ }^{3}$ В настоящее время - Национальный музей им. Алдан-Маадыр Республики Тыва.
} 


\section{НОВЫЕ ИССЛЕДОВАНИЯ ТУВЫ}

www.nit.tuva.asia

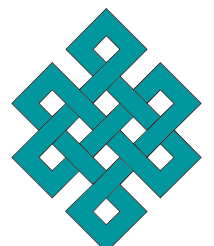

2020

\section{THE NEW RESEARCH OF TUVA}

Novye issledovaniia Tuvy

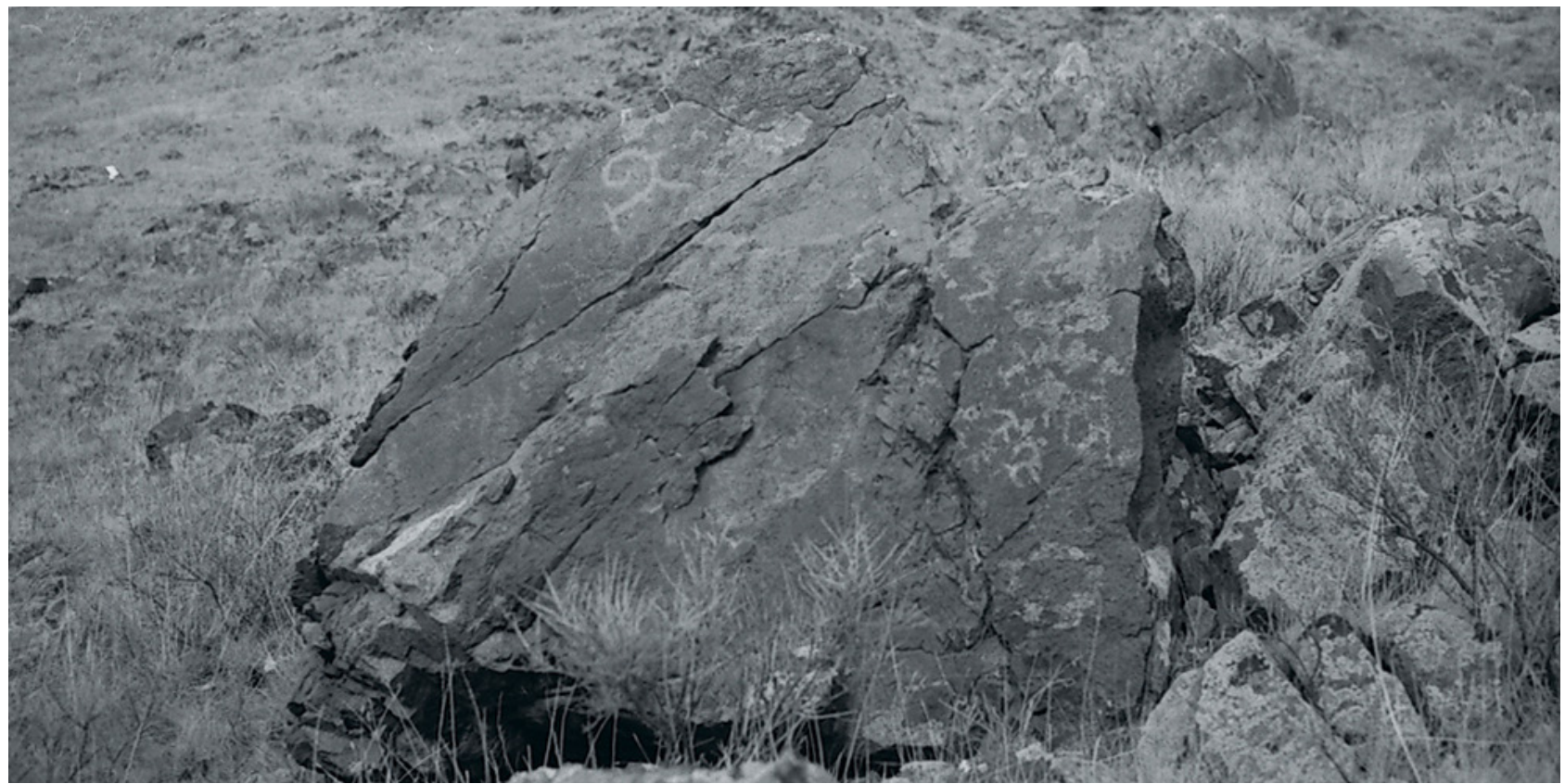

Фото 5. Наскальные изображения на отрогах Чуруктуг-Кырлан. Фото А. Д. Грача, 1953 г. МАЭ И 1595-266. Photo 5. Rock carvings on the Chyryktug-Kyrlan. Photo by A. D. Grach, 1953. MAE I 1595-266.

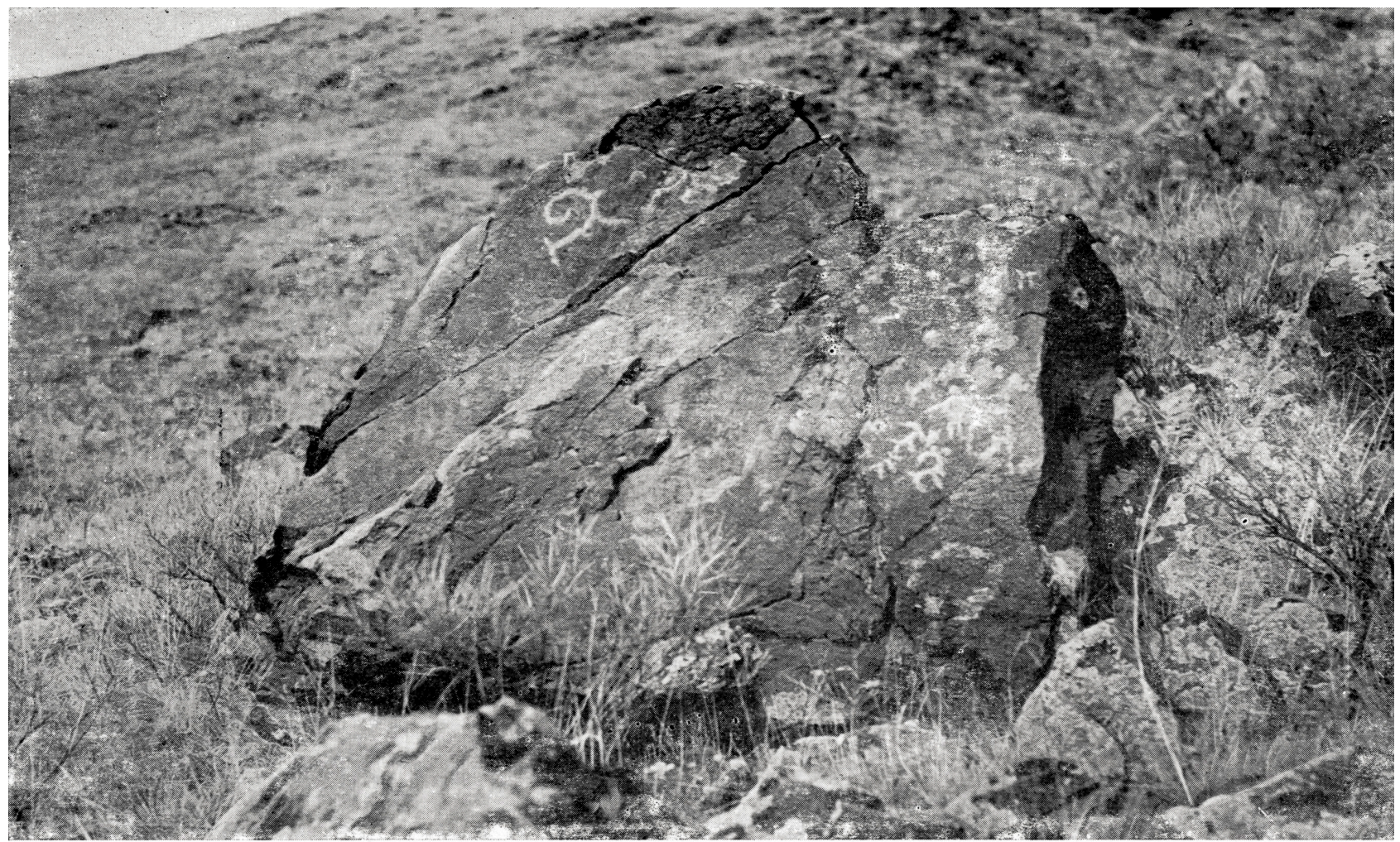

Фото 6. Изображение из публикации А. Д. Грача (Грач, 1957: лист-вклейка, табл. I).

Photo 6. An image from one of A. D. Grach's publications (Grach, 1957; Plates, table 1).

иллюстрации это - чаще выявление, подчеркивание важных деталей. В большинстве случаев чернобелые изображения в публикациях второй половины XX в. имели ярко выраженную зернистость и несбалансированную контрастность, что приводило к ухудшению восприятия публикуемых фотографий. Хотя за неимением лучшего, такой иллюстративный материал был единственным визуальным источником. Качество изображений также могло ухудшаться от публикации к публикации, 


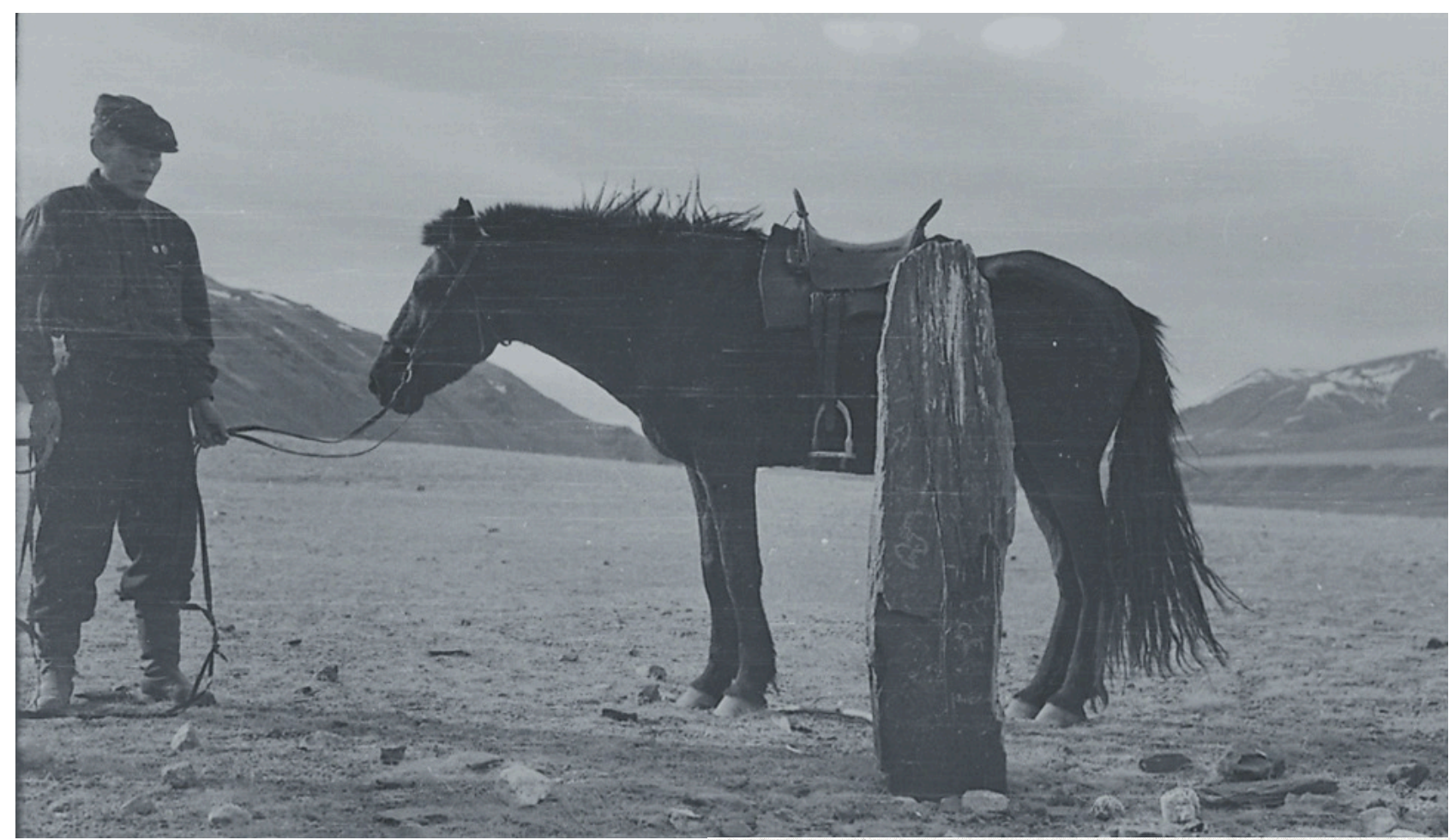

Фото 7. У стелы с изображениями древнетюркского времени.

Долина реки Каргы, к северо-западу от села Мугур-Аксы.

Фото А. Д. Грача, 1953 г. МАЭ И 1595-59.

Photo 7. At the stele with Old Turkic images, valley of the Kargy river, North-west from Mugur-Aksy village. Photo by A. D. Grach, 1953. MAE I 1595-59.

Фото 8. Изображение из публикации А. Д. Грача 1955 2. (Грач, 1955: 408).

Photo 8. An image from one of A. D. Grach's publications (Grach, 1955: 408).

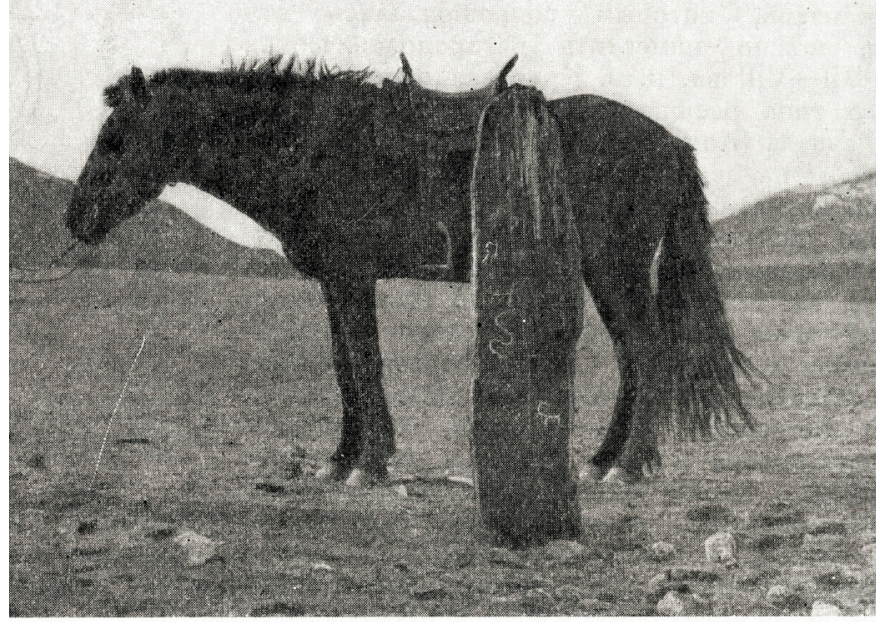

если каждый раз для получения типографского клише не использовался первоначальный негатив, либо не использовалось одно и то же клише, что затруднительно в случае временного разрыва между публикациями, изданиями в типографиях различной подчиненности и использования негативов, являющихся частью музейных коллекций.

Собрания негативов, зарегистрированные А. Д. Грачом и позднее опубликованные им, наглядно демонстрируют описанные выше особенности работы с полевыми материалами. Например, кадрирование и увеличение контрастности изображений (фото 5) для публикации в статье о петроглифах Тувы (Грач, 1957) обосновано, так как фотографии должны были четко отражать содержание наскальных изображений (фото 6).

Для А. Д. Грача в экспедиции 1953 г. каменные изваяния оказались более сложными объектами для съемки. На большинстве снимков рядом с каменными фигурами, оградками или плитами оказывались люди, лошади или фон был не совсем удачным для передачи деталей древних памятников. Поэтому чаще всего эти снимки при подготовке к публикации подвергались кадрированию.

Так, снимок с изображением стелы в долине реки Каргы (фото 7) для печати в Сборнике Музея антропологии и этнографии (Грач, 1955: 408), был кадрирован - вырезана фигура спешившегося всадника и изменена контрастность области вокруг стелы. При этом качество печати не позволило 
четко обозначить границы между стелой и фигурой лошади, на фоне которой заснят древний памятник (фото 8), в отличие от современного цифрового изображения, которые мы получаем путем сканирования и обращения исходного негатива в позитивное изображение.

\section{Основные сюжеты в коллекциях Е. Д. Прокофьевой и их использование в публи- кациях собирателя}

Частота использования Е. Д. Прокофьевой материалов, отснятых ею и её коллегами в экспедициях 1952-1953 гг., не столь представительна, как у А. Д. Грача.

Восемь фотографий с этнографическими и советскими сюжетами были опубликованы исследовательницей в «Кратких сообщениях Института этнографии АН СССР» (Прокофьева, 1955). Некоторые кадры из первых экспедиций Тувинского отрада стали частью иллюстративного аппарата монографии Е. Д. Прокофьевой «Процесс национальной консолидации тувинцев», которая была написана в 1957 г. Но этот труд, уточняющий и дополняющий этнографию тувинцев, остался неизданным, так как Л. П. Потапов отказал Прокофьевой в публикации рукописи. Также ей было предложено «прекратить изучение Тувы и вернуться к исследованиям селькупов» (Кисель, 2011b: 25). Исследователи связывают такую судьбу рукописи с конкуренцией в научной сфере. Фундаментальный труд Е. Д. Прокофьевой был опубликован полвека спустя в серии монографий «Кунсткамера - Азия» (Прокофьева, 2011), благодаря кропотливой работе В. А. Киселя по редактуре и восстановлению фрагментов рукописи, хранящейся в Научном архиве МАЭ (Архив МАЭ РАН, ф. К-І, оп. 1, д. 560-562).

Поскольку в рукописи отсутствует много фотографий и рисунков (об этом пишет В. А. Кисель: Кисель, 2011а: 11-12), то публикация монографии в 2011 г. была дополнена фотографиями из архива МАЭ и из упоминавшейся выше статьи исследовательницы (Прокофьева, 1955). Из 32 фотографий, используемых в монографии, к коллекциям, зарегистрированным лично Е. Д. Прокофьевой, относится

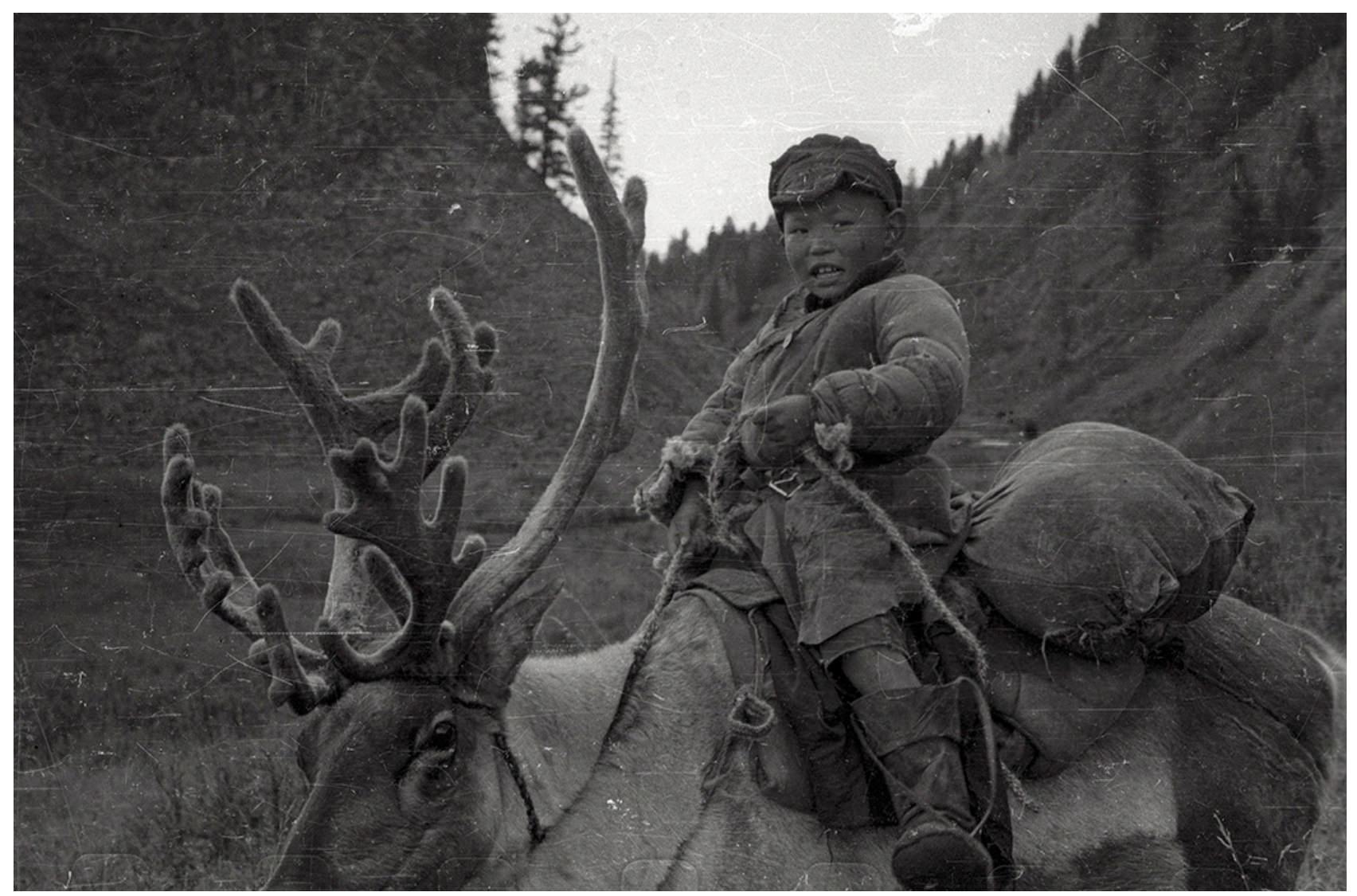

Фото 9. Восьмилетний сын пастуха-оленевода Миша едет на олене на учебу в колхозный поселок. Тоджинский кожуун, тайга Удеген. Фото Е. Д. Прокофьевой, 1952 г. МАЭ И 1612-118.

Photo 9. Misha, an eight-year-old son of a reindeer herder rides a deer to his school at a kolkhoz settlement. Todzhu kozhuun, Udegen taiga. Photo by Ye. D. Prokofieva, 1952. MAE I 1612-118. 


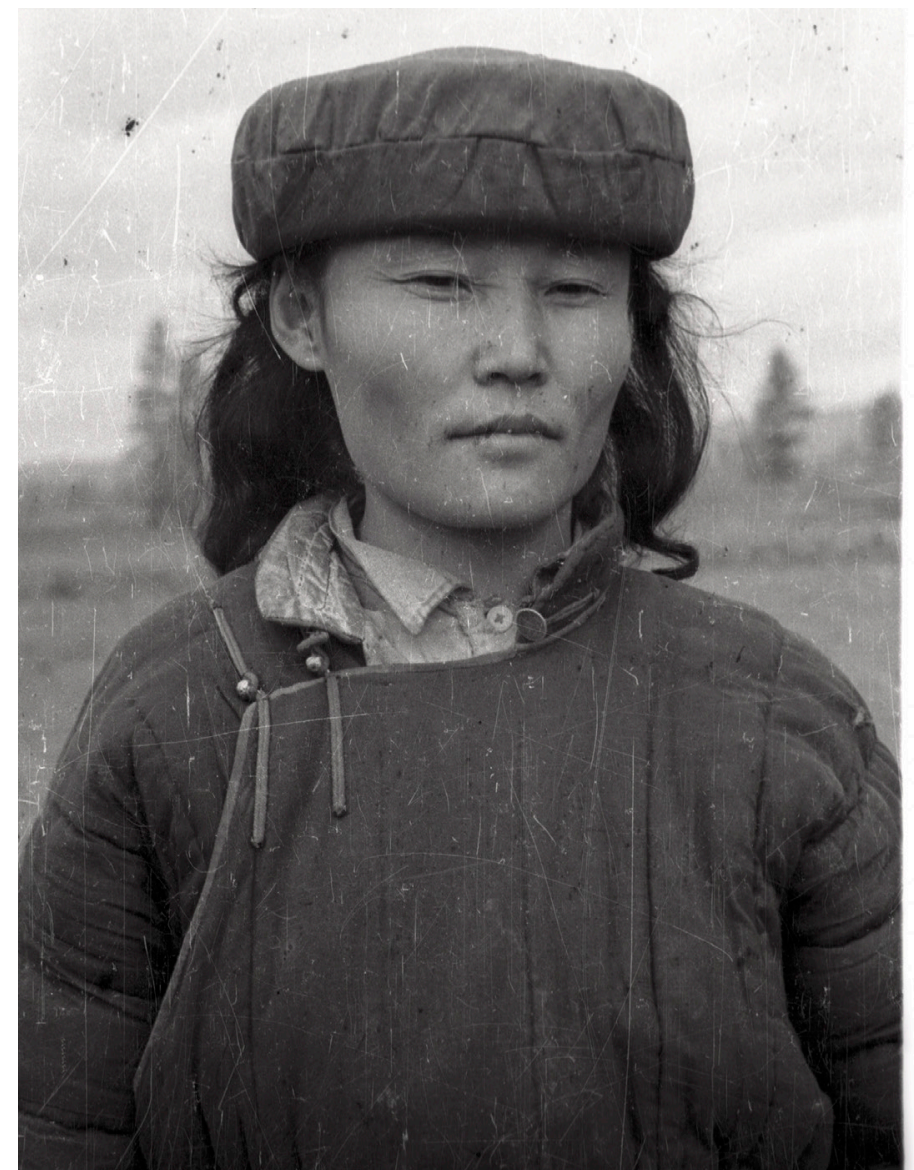

Фото 10. Ак Тингмэ - охотница-соболятница колхоза «1 Мая». Тоджинский кожуун.

Фото Е. Д. Прокофьевой, 1952 г. МАЭ И 1612-299.

Photo 10. Ak Tingme, a sable hunter of the "May 1" kolkhoz. Todzhu kozhuun.

Photo by Ye. D. Prokofieva, 1952. MAE I 1612-299.

8 снимков $^{1}$; зарегистрированным А. Д. Грачом $-7^{2}$. Редакторы монографии использовали две фотографии ${ }^{3}$ из публикации Прокофьевой и наибольшее число фотографий - 15 было взято из Научного архива МАЭ.

Говоря об этнотематике коллекций фотонегативов, полученных Е. Д. Прокофьевой, стоит отметить, что ее материалы иллюстрируют разные стороны жизни тувинцев. Это и традиционные занятия кочевого населения (оленеводство, охота) и новые реалии жизни советской Тувы. Часто на снимках встречаются изображения домашнего скота - овец, коров, лошадей и оленей.

Нисколько не умаляя научной ценности и уникальности в своем роде фотографий Е. Д. Прокофьевой, нужно отметить, что содержание коллекций несет на себе отпечаток советской эпохи. Это выражается, прежде всего, в большом количестве снимков, которые были призваны отражать результаты советской модернизации села и выделять новых героев социалистического строительства. Ход истории вносил свои коррективы в образ жизни тувинцев. На кадрах из экспедиций можно увидеть неспешное вплетение новых реалий в привычный уклад жизни. И описания к негативам в коллекционных описях Е. Д. Прокофьевой как нельзя лучше демонстрируют этот контраст наряду с визуальным материалом. Например, в поле зрения объектива попадает Миша Параан восьмилетний сын пастуха-оленевода, который едет с пастбищ через тайгу Удеген на олене в тувинскую начальную школу в колхозе «Советская Тува» (фото 9; МАЭ РАН, опись коллекции МАЭ И 1612, л. 17).

Большинство портретов, сделанных Е. Д. Прокофьевой, представляют собой антропологическую съемку, описание к которым интересно и историкам, и этнографам. Так серия женских портретов из коллекции МАЭ И 1612 показывает нам основные типажи, особенности костюма, является рядовым антропологическим материалом, отличается художественным почерком фотографа и дополняется информативными текстами в описи. Из документов становится известно, что в охотничьей бригаде колхоза «1 Мая» работало 13 женщин. Из них четверо лучших охотниц - Ак Чезибан, Ак Тингмэ (фото 10), Ак Маримаа и Ак Оханды «были «допущены» к самому сложному промыслу - охоте на соболя» (МАЭ РАН, опись коллекции МАЭ И 1612, л. 39).

Женщины промышляли первую, более простую половину охотничьего сезона (с 25 октября по 20 декабря) на оленях (МАЭ РАН, опись коллекции МАЭ И 1612, л. 37).

${ }^{1}$ РИс. 6 - МАЭ И 1612-396, рис. 7 - МАЭ И 1612-60, рис. 15 - МАЭ И 1612-186, рис. 41 - МАЭ И 1612-343, рис. 42 - МАЭ И 1612-337, рис. 54 - МАЭ И 1612-388, рис. 55 - МАЭ И 1612-389, рис. 57 - МАЭ И 1612-390 согласно нумерации иллюстраций в монографии (Прокофьева, 2011: 209, 213, 219, 312, 314, 436, 437, 438).

${ }^{2}$ Рис. 25 - МАЭ И 1595-103, рис. 28 - МАЭ И 1595-351, рис. 29 - МАЭ И 1595-149, рис. 38 - МАЭ И 1595-404, рис. 43 - МАЭ И 1595-241, рис. 44 - МАЭ И 1595-391, рис. 45 - МАЭ И 1595-491 согласно нумерации иллюстраций в монографии (Прокофьева, 2011: 289, 294, 294, 309, 316, 318, 320) и учетной документации МАЭ.

${ }^{3}$ Рис. 32 и рис. 60 согласно нумерации иллюстраций в монографии (Прокофьева, 2011: 297, 446). 
Помимо фотографий местных жителей, в коллекциях, собранных Е. Д. Прокофьевой, имеются групповые и одиночные портреты членов Тувинского отряда 1952-1953 гг. ${ }^{1}$

\section{Заключение}

Состав коллекций фотографических негативов из Саяно-Алтайских экспедиций 1952 и 1953 гг., их характеристики, позволяют заключить, что материалы имеют большую научную и культурную ценность, поскольку изображения отличаются своей репрезентативностью и информативностью.

Проблемой в изучении коллекций негативов является недостаток информации о фотографах, изображенных сюжетах и лицах, отсутствие точной датировки, краткость описаний, недостаток информации об использовании изображений в публикациях исследователей.

Сопоставив исходные негативы из коллекций МАЭ с изображениями, опубликованными А. Д. Грачом и Е. Д. Прокофьевой, были внесены предложения по изменению названий негативов, как музейных предметов. В ходе работы был определен ряд сюжетов, работа с которыми требует обращения к полевым архивным материалам. В процессе составления научных описаний негативов были выявлены тематические блоки, имеющие научный потенциал с точки зрения историографии изучения Тувы и с учетом ранее опубликованных исследований о научной деятельности А. Д. Грача и Е. Д. Прокофьевой.

Переосмысление советских сюжетов в фотографической съемке, введение в научный оборот ранее неопубликованных портретов научных деятелей, рабочих моментов экспедиционной работы, расширение источниковой базы по краеведению за счет использования редких экспедиционных кадров, публикация экспедиционных материалов с использованием современных возможностей полиграфии представляются наиболее перспективными в дальнейшей работе с материалами Тувинского отряда Саяно-Алтайской экспедиции из собрания Кунсткамеры.

\section{СПИСОК ЛИТЕРАТУРЫ}

Вайнштейн, С. И. (1961) Тувинцы-тоджинцы. Историко-этнографические очерки. М. : Наука. 218 с.

Вайнштейн, С. И. (1972) Историческая этнография тувинцев: Проблемы кочевого хозяйства. М. : Наука. 315 с.

Вайнштейн, С. И. (2009) Загадочная Тува. М. : Домашняя газета. 416 с.

Грач, А. Д. (1955) Каменные изваяния западной Тувы (к вопросу о погребальном ритуале тугю) // Сборник Музея антропологии и этнографии. М. ; Л. : Изд-во АН СCCР. Т. XVI. 461 с. С. 401-431.

Грач, А. Д. (1957) Петроглифы Тувы, І. (Проблема датировки и интерпретации, этнографические традиции) // Сборник Музея антропологии и этнографии. М. ; Л. : Изд-во АН СССР. Т. XVII. 541 с. С. 385-428.

Грач, А. Д. (1961а) Древнетюркские изваяния Тувы. М. : Издательство восточной литературы. 96 с.

Грач, А. Д. (1961b) Древнетюркские изваяния Тувы: по материалам исследований 1953-1960 гг.: дисс. ... канд. ист. наук. М. 138 с.

Грач, А. Д. (1980) Древние кочевники в центре Азии. М. : Наука. 256 с.

Дьяконова, В. П. (1975) Погребальный обряд тувинцев как историко-этнографический источник. Л. : Наука. $164 \mathrm{c}$.

Иргит, Ч. К. (2013) Периодизация истории этнографического изучения тувинцев [Электронный ресурс] // Новые исследования Тувы. № 3. URL: https://nit.tuva.asia/nit/article/view/221 (дата обращения: 07.05.2020).

Каралькин, П. И. (1960) Жилище в Западной Туве // Труды Тувинской комплексной археолого-этнографической экспедиции 1955-1956 гг. М. ; Л. : Издательство Академии наук СССР. Т. I. 312 с. С. 267-283.

Кисель, В. А. (2011а) Предисловие // Прокофьева Е. Д. Процесс национальной консолидации тувинцев. СПб. : Наука. 538 с. С. 9-12.

\footnotetext{
${ }^{1}$ А. Д. Грач на групповых портретах: МАЭ И 1611-58, МАЭ И 1611-65, МАЭ И 1611-67, МАЭ И 1611-112, МАЭ И 1611-117, МАЭ И 1611-165, МАЭ И 1611-166, МАЭ И 1611-310, МАЭ И 1611-311, МАЭ И 1611-358, МАЭ И 1611-366, МАЭ И 1611-367, МАЭ И 1611-449. Индивидуальные портреты А. Д. Грача: МАЭ И 1611-6, МАЭ И 1611-56, МАЭ И

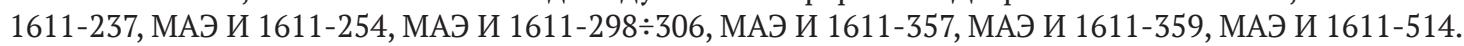

Е. Д. Прокофьева на групповых портретах: МАЭ И 1611-65, МАЭ И 1611-67, МАЭ И 1611-358, МАЭ И $1612-52$. Индивидуальные портреты Е. Д. Прокофьевой: МАЭ И 1611-57, МАЭ И 1611-66, МАЭ И 1611-361, МАЭ И $1611-513$.
} 
Кисель, В. А. (2011b) Забытый исследователь Тувы // Прокофьева Е. Д. Процесс национальной консолидации тувинцев. СПб. : Наука. 538 с. С. 13-27.

Кисель, В. А. (2012) Тува в судьбе этнографа Е. Д. Прокофьевой [Электронный ресурс] // Новые исследования Тувы. № 2. URL: https://nit.tuva.asia/nit/article/view/336/665 (дата обращения: 07.05.2020).

Потапов, Л. П. (1969) Очерки народного быта тувинцев. М. : Наука. 402 с.

Прокофьева, Е. Д. (1955) Некоторые этнографические данные о тувинцах западных районов Тувинской автономной области // Краткие сообщения Института этнографии АН СССР. Вып. 23. С. 3-18.

Прокофьева, Е. Д. (2011) Процесс национальной консолидации тувинцев. СПб. : Наука. 538 с.

Савинов, Д. Г., Длужевская, Г. В. (1998) Этапы жизни ученого // Древние культуры Центральной Азии и СанктПетербург: Материалы Всероссийской научной конференции, посвященной 70-летию со дня рождения Александра Даниловича Грача. г. Санкт-Петербург, декабрь 1998 г. / отв. ред. Д. Г. Савинов. СПб. : Культ-информ-пресс. 304 с. C. 7-9.

Дата поступления: 15.05.2020 2.

\section{REFERENCES}

Vainshtein, S. I. (1961) Tuvintsy-todzhintsy. Istoriko-etnograficheskie ocherki [Tozhu tuvans: historical and ethnographic essays]. Moscow, Nauka. 218 p. (In Russ.).

Vainshtein, S. I. (1972) Istoricheskaia etnografiia tuvintsev. Problemy kochevogo khoziaistva [Historical Ethnography of Tuvans. Problems of nomadic economy]. Moscow, Nauka. 314 p. (In Russ.).

Vainshtein, S. I. (2009) Zagadochnaia Tuva. [The mysterious Tuva]. Moscow, Domashniaia gazeta, 416 p. (In Russ.)

Grach, A. D. (1955) Kamennye izvaianiia zapadnoi Tuvy (K voprosu o pogrebal'nom rituale tugiu) [Stone statues of the West Tuva: on the Tugu burial ritual Tugu)]. In: Sbornik Muzeya antropologii i etnografii [The Collection of the Museum of Anthropology and Ethnography]. Vol. XVI. 461 p. Pp. 401-431. (In Russ.)

Grach, A. D. (1957) Petroglify Tuvy, I. (Problema datirovki i interpretatsii, etnograficheskie traditsii) [Petroglyphs in Tuva. Part I. The problems of dating, interpretation and ethnographic traditions]. In: Sbornik Muzeya antropologii $i$ etnografii [The Collection of the Museum of Anthropology and Ethnography]. Vol. XVII. 541 p. Pp. 385-428. (In Russ.)

Grach, A. D. (1961a) Drevnetiurkskie izvaianiia Tuvy [Ancient Turkic statues of Tuva]. Moscow, Vostochnaya literature Publ. 96 p. (In Russ.)

Grach, A. D. (1961b) Drevnetiurkskie izvaianiia Tuvy: po materialam issledovanii 1953-1960 gg. [Ancient Turkic statues of Tuva: based on research materials collected in 1953-1960]. Diss. ... Candidate of History. Moscow. 138 p. (In Russ.)

Grach, A. D. (1980) Drevnie kochevniki v tsentre Azii [Ancient nomads in Central Asia]. Moscow, Nauka. 256 p. (In Russ.).

D'iakonova, V. P. (1975) Pogrebal'nyi obriad tuvintsev kak istoriko-etnograficheskii istochnik [The funeral rite of the Tuvans as a historical and ethnographic source]. Leningrad, Nauka. 164 p. (In Russ.)

Irgit, Ch. K. (2013) Periodizatsiia istorii etnograficheskogo izucheniia tuvintsev [Periodization of the history of ethnographical study of Tuvans]. The New Research of Tuva, no. 3 [online] Available at: https://nit.tuva.asia/nit/article/ view/221 (access data: 07.05.2020).

Karal'kin, P. I. (1960) Zhilishche v Zapadnoi Tuve [Housing in Western Tuva]. In: Trudy Tuvinskoi kompleksnoi arkheologoetnograficheskoi ekspeditsii 1955-1956 gg. [Tuva complex archaeological and ethnographic expedition of 1955-1956.]. Moscow, Leningrad, Izdatel'stvo Akademii nauk SSSR. Vol. I. 312 p. Pp. 267-283. (In Russ.)

Kisel', V. A. (2011) Predislovie [Preface]. In: Prokof'eva E. D. Protsess natsional'noi konsolidatsii tuvintsev [The Process of National Consolidation of the Tuvans]. St. Petersburg, Nauka. 538 p. Pp. 9-12. (In Russ.)

Kisel', V. A. (2011) Zabytyi issledovatel' Tuvy [A forgotten researcher of Tuva]. In: Prokof'eva E. D. Protsess natsional'noi konsolidatsii tuvintsev [The Process of National Consolidation of the Tuvans]. St. Petersburg, Nauka. 538 p. Pp. 13-27. (In Russ.)

Kisel', V. A. (2012) Tuva v sud'be etnografa E. D. Prokof'evoi [Tuva in anthropologist E. D. Prokofieva's doom]. New Research of Tuva, no. 2. URL: https://nit.tuva.asia/nit/article/view/336 (access data: 07.05.2020).

Potapov, L. P. (1969) Ocherki narodnogo byta tuvintsev [The Tuvans: sketches of the folk lifestyle and related household activities]. Moscow, Nauka, GRVL. 402 p. (In Russ.).

Prokofieva, E. D. (1955) Nekotorye etnograficheskie dannye o tuvintsakh zapadnykh raionov Tuvinskoi avtonomnoi oblasti [Some ethnographical data about Tuvans in west regions of Tuva]. In: Kratkie soobshcheniia Instituta etnografii AN SSSR [Short reports of Institute of Ethnography]. Vol. 23. Pp. 3-18. (In Russ.) 
Prokof'eva, E. D. (2011) Protsess natsional'noi konsolidatsii tuvintsev [The Process of National Consolidation of the Tuvans]. St. Petersburg, Nauka. 538 p. (In Russ.).

Savinov, D. G. and Dluzhevskaia, G. V. (1998) Etapy zhizni uchenogo [Stages of scientist's life]. In: Drevnie kul'tury Tsentral'noi Azii i Sankt-Peterburg [Ancient cultures of Central Asia and St. Petersburg]: All-Russian conference (St. Petersburg, December, 1998): reports. St. Petersburg, Kul't-inform-press. 304 p. Pp. 7-9. (In Russ.)

Submission date: 15.05 .2020$. 